\title{
Metaphorical and literal readings of aphorisms in the Book of Proverbs
}

\author{
James Alfred Loader \\ Institut für Alttestamentliche Wissenschaft und Biblische Archäologie \\ University of Vienna \\ Professor Extraordinarius, UNISA
}

\begin{abstract}
Starting with a recently proposed thesis that the key to recognizing the coherence of Proverbs' discourse of wealth and poverty should be seen in an appreciation of the text's figurative interpretive possibilities, it is here argued that criticism of an "overly literal" interpretation of the Book of Proverbs is not well served by an "overly figurative" reading. A detailed analysis of the book's proemium is offered to substantiate the argument that even as hermeneutical key to the anthology as a whole, it does not warrant a tendency to the figurative reading of aphorisms. It is further contended by means of illustrations from aphorisms within the poems and independent sayings that difficulties arise when such a reading is attempted on any appreciable scale. As a corollary, illustrations of the many instances where literal readings are necessary, so that such an overriding hermeneutical perspective cannot be convincing. Interpreting a metaphor is one thing, reading metaphorically is another, notably a creative act independent of whether its "correctness" can be demonstrated by arguments from the redactional frame or the possible relationship of the collected aphorisms to folk sayings.
\end{abstract}

\section{INTRODUCTION}

In a recent monograph published in the prestigious Biblical Interpretation Series, the Chicago professor of Hebrew Bible, Timothy Sandoval, proposes a bold thesis on the basis of an investigation of what he calls "the discourse of wealth and poverty in the Book of Proverbs". Focusing on "metaphor" and "discourse" and to a great degree depending on Paul Ricoeur, he argues that the book's discourse on wealth and poverty is "more coherent than is usually thought and plays an integral role in the book's construction of a moral vision for its reader or hearer." 
This is extremely interesting, since it prompts several further questions:

- $\quad$ whether the perceived coherence, being part of the whole book's strategy in constructing a unitary moral vision, can also be observed within other "discourses" found in the book or in its presentation of other topics, such as trustworthiness, industriousness, the royal court and so on;

- whether these "discourses" are coherent among and in themselves;

- whether the roles played by such different aspects contribute by virtue of their unity to the moral vision;

- if so, what is special about the discourse of wealth and poverty, and if not, is a general coherence of argumentative material not to be expected in a book of which it can be claimed that it has one "moral vision"?

For the moment I shall not pursue these questions in any depth, since they provide a backdrop to what specifically interests me for the purposes of this paper, notably another idea exploited by Sandoval for the development of his argument. He continues in the review of his procedure: ${ }^{1}$

The key to recognising the coherence of Proverbs' discourse of wealth and poverty is an appreciation of the text's figurative interpretive possibilities. The Book's prologue, which articulates the primary virtues and goals of Proverbs, itself invites the wise and discerning reader at the outset of the instruction to consider the book's tropes and figures. With various individual meshalim, other internal cues, such as the difficulties or absurdities posed by a literal interpretation, likewise point to the text's figurative qualities.

The survey is consistently developed in the book and the importance of the prologue as hermeneutical "cue" is not co-incidentally stressed. In a detailed discussion of Proverbs 1:2-7 Sandoval (2006:45-57) develops the idea that the "tropes and figures" of verse 6 are intended to suggest that readers should be sensitised to find "figurative" meanings all over the book. If this is true, it would have to hold good for the Book of Proverbs as such and not only for the discourse of wealth and poverty.

I do not dispute the idea that the prologue provides a hermeneutical indication of how the book as a redactional composition is to be read. But

${ }^{1}$ Sandoval (2006:205). 
using this insight for all practical purposes as an argument to slant the reader towards a "figurative" reading of the book, or at least a "more figurative" reading than would otherwise have been the case, in my opinion grossly overestimates its possibilities. I shall therefore offer an alternative interpretation of the "hermeneutical cue" and then proceed to offer some illustrations of difficulties I perceive when trying to read "overly figuratively" as an alternative to what Sandoval calls "overly literalistic" readings. As a corollary, I shall then come to some illustrations of many instances where literal readings are not only possible, but also necessary. Together, these considerations will show that such an overriding "metaphorical" or "symbolical" hermeneutical perspective cannot be regarded as convincing.

\section{EVIDENCE FROM THE TEXTUAL MATERIAL}

I begin with the connected text of the prologue and then turn to a selection of aphorisms to substantiate my argument.

\subsection{Proverbs 1:1-7}

1 The proverbs of Solomon son of David, king of Israel.

2 For getting to know wisdom and discipline, for understanding the words of insight,

3 for gaining instruction in wise conduct, righteousness, justice and honesty,

4 for giving the simple shrewdness, knowledge and circumspection to the young.

$5 \mathrm{~A}$ wise man should listen to expand learning and a discerning man to acquire skills,

6 in order to explain a proverb and a figure, the words of the wise and their riddles.

7 The fear of Yahweh is the beginning of knowledge; fools despise wisdom and instruction.

First comes the title ( $v 1$ ) and an expansion, qualifying the title itself and therefore specifying the contents of the book in the manner of what we would call a subtitle (vv 2-4), then a summarising injunction ( $v v 5-6$ ), and finally the motto of the book ( $\vee 7)$.

\footnotetext{
${ }^{2}$ For the translation and structural sketch, cf Loader (2004:418-20); because of the pivotal importance of the proemium for the thesis that the reading of the anthology should be slanted towards the symbolic, figurative or metaphorical reading of aphorisms, I now offer a somewhat fuller account of the content.
} 
Although the various parts of the introduction show signs of not having originated at the same time, they have been edited together into one passage prefacing the whole of the Book of Proverbs as we have it in its present Hebrew form. The first passage of the Book of Proverbs illustrates the oft overlooked interface between the synchronic analysis of a composite text and its diachronic aspects as well as the significance of this for its meaning. It can be read in several ways.

- First, the series of infinitives in vv 2-4 and 6 can be taken as directly dependent on the heading in $v 1$ : "The Proverbs of Solomon, son of David, king of Israel, to learn wisdom and instruction" et cetera (structure: vv 1-6 $+7)$.

- Second, it is more probable that the infinitives of vv 2-4 depend on the heading and that of $v 6$ on the injunction(s) in v 5 (structure: vv 1+2-4; 5-6; 7 ). This is substantiated by the fact that the sequence of infinitives is interrupted by either one or two injunctions in $v 5,{ }^{3}$ as well as the fact that the infinitive להבין in v 6 is more naturally taken as dependent on this injunction / these injunctions, rather than on the verbless superscription in v 1: The expansion of learning and the acquisition of skills ( $v 5$ ) are intended to clarify the difficult sayings of the wise ( $v 6)$ - which typifies the book as literature for teachers.

- In the third place it is entirely possible that vv 5-6 are a redactional addition, which seems to be suggested by the fact that the series of infinitives and nouns in vv 2-4 concern general sapiential ideas, whereas v 6 refers to four quite specific wisdom genres. This is a diachronic argument involving the meaning of words and rendering the same structure as the one just described (vv 1+2-4; 5-6; 7). In any event vv 2-4 focus on the trainees and what they need, while vv 5-6 focus on the trainers and how they can provide in the needs of the young.

- Fourth, it remains thinkable, if improbable, that $\vee 5$ was added later as a parenthetical addition, so that the series of infinitives may have originally continued in v 6 (structure: vv 1+2-4.6; 7). In this case להבין would have the same meaning as in v 2 ("understand" instead of "explain").

The repeated use of $ל$ with the infinitive construct (augmented by $ל$ with a noun in v 4b) has a marked alliterative effect, rendered all the more effective

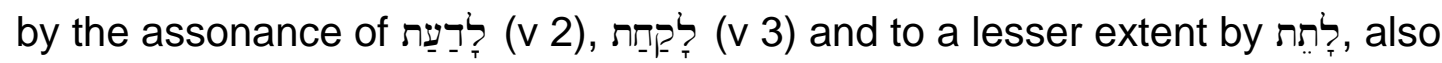

\footnotetext{
${ }^{3}$ Either: "A wise man should listen to expand learning and a discerning man to acquire skills" (one injunction) or: "A wise man should listen to expand learning and a discerning man should acquire skills" (two injunctions).
} 
involving five dental sounds. Within vv 2-6 there is a little inclusio in that the last hemistich of $v 2$ and the first hemistich of $v 6$ begin with להבין.

1 The nature of what is to follow in the book is identified by describing the contents as "Solomon's Proverbs". This king was regarded by tradition as the

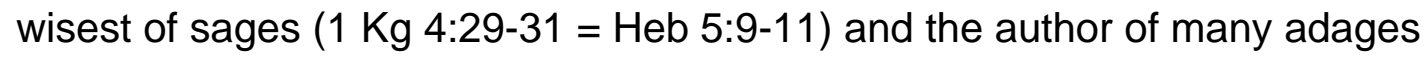
(1 Kg 4:32-33 = Heb 5:12-13). Although the editor could therefore not have excluded the possibility that King Solomon actually did compose proverbs in the tenth century BCE, he could not have intended his caption to be taken literally, that is, in the sense that Solomon was the author of all the proverbs in the book.

2 The important word for our purposes is 2 , which occurs in verses 2 and 6 and is of crucial importance for the question facing us. In the Hiphil, this verb means "to understand" as it does in the Qal. Because of the close synonymous parallelism to לָדבֵַת "get to know", the other possibility, "to explain" (cf below on $v 6$ ), is excluded in $v 2$. The verb has a decided intellectual component, although it does not only refer to the mere awareness of facts, but includes discernment and reason. It often occurs, as here, in association with חכם and, even in non-sapiential literature (Ringgren 1973:623) and can mean "observe" (e g Pr 7:7), "pay attention" (e g Pr 14:8, 15) and "gain insight" (e g Pr 20:24). The semantic aspects involved in these uses of the word are closely related and the differences in nuance are often a matter of focus. Thus, to achieve understanding includes attentive observation, which is clearly intended here, since $ל$ with the infinitive is a final construction indicating purpose: this book is for learning. The object follows:

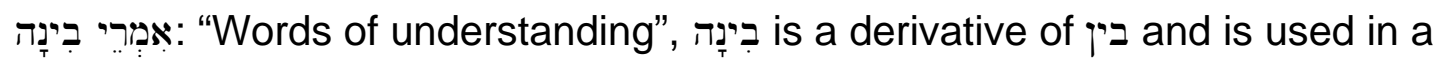
construction akin to, but not identical with, a figura etymologica (since it is not the direct object of the cognate verb but itself imbedded in a genitive construction). We here have a qualitative genitive: understanding qualifies the words. This may be interpreted in two ways, either as words that lead to understanding or as words that spring from understanding. Both apply in the present context, for the wise impart insight and the pupils acquire it. These "words" may be taken generally to include all the words of the wise, including the spoken ones, but in the context of the preface to a book they refer primarily to the written words that follow. For the pairing of בדָמָּה $\operatorname{Pr} 4: 1,5,7 ; 7: 4 ; 8: 14 ; 9: 6,10 ; 16: 16 ; 23: 23 ; 30: 2)$. Wisdom and understanding are conveyed by words in the first place. In this way the primary purpose of the book ( $\mathrm{v} 2 \mathrm{a}$ ) is elucidated: given acceptance of authority, the skills of life 
are acquired by paying attention to words of understanding, so that the same insight may be attained as that from which the words of the teachers spring. This throws into relief the discipline spoken of in the first hemistich: Whoever wishes to benefit, must pay attention, since the method for acquiring wisdom consists of heeding the insightful words of the wise, including those written in the present book.

3 The contents of the wisdom to be so acquired are unfolded by further technical terms.

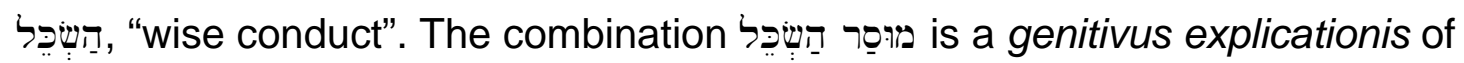
the type indicating purpose: the training in question is specified by the wise conduct expected to result from it.

צֶיר, righteousness is the general term for that which is in accordance with the normative order of society and the world. ${ }^{4}$ This may be a term designating "purely moral qualities", but that is no reason to regard them as "different in kind from all the other abstract qualities listed in these verses" (Whybray 1994:32). On the contrary, neither sapiential injunctions nor adages can achieve the prospects introduced here without a normative basis. The practical turn of sapiential literature does not at all imply a lack of moral perspective. This is amply illustrated by the fact that the immediately following words often occur in the Book of Proverbs.

פִש justice is the realisation of what is right in actual social and juridical practice. In addition to our verse, it often occurs in the book, both in the poems of chapters 1-9 (cf $\operatorname{Pr} 2: 8,9 ; 8: 20$ ) and in the adages of chapters 10-29 (cf Pr 12:5; 13:23; 16:8, 10, 11; 17:23; 19:28; 21:3, 7, 15; 28:5; 29:26).

מִישִָׁרים a far less common word, is a generic term to denote what is generally right (ישר) and includes straightforwardness, rectitude and honesty. Its generality may be imitated by the translation "uprightness". It also occurs in $\mathrm{Pr}$ 2:9 (also in combination with righteousness and justice), in 8:6 and 23:16 (both times in this general sense), and in 23:31 (but here as part of an adverbial construction).

This is, then, what life-skill entails. Wisdom, as the practising of justice in society, is an undertaking of straightforward honesty in accordance with the

\footnotetext{
${ }^{4}$ According to A Ho (1991), a work devoted to "Sedeq and Sedaqah in the Hebrew Bible," the former is a general term including righteousness and justice, whereas the latter is an ethical "state of being," which stands the usual distinction between the two on its head.
} 
prevailing normative order. Whose order this is, who stands behind its norms, will presently become clear $(v 7)$.

$4 \quad$ Next, the recipients of the sapiential enterprise are mentioned. Certain qualities are "given" (לָ (לָת) to them, which not only means that they are the beneficiaries of the training, but also implies a source that imparts the sapiential qualities to the receivers. This may be read in two ways: both the people who teach and the book itself may be taken as the source. In the present context the latter would be the most natural. This book is for imparting sapiential qualities. Even so, however, the association of discipline and training with the enterprise (מוסר occurs in both preceding verses) points to the presupposition that the Book of Proverbs is to be used by teachers for the conveying of the qualities and qualifications in question. This suggests that, by the time of the final redaction of the book - when the title and preamble (vv 17) were put in their present position - there could have been people who needed a book like this for the instruction of the youth. The primary readership of the book is, accordingly, not seen as the young trainees themselves, but the educators (see below on $v 5$ ). Quite apart from the question of how formal or institutional the undertaking was, it may be said that the book is a collection of materials for use in teaching.

פתמָאים: These are the simple in the sense of inexperienced and naive. They are susceptible to outside influences and therefore to the salutary effects of sapiential teaching, but also to negative influences and may therefore be associated with fools (cf vv 22, 32; $\operatorname{Pr} 8: 5$ ).

עָרָָָה: The shrewdness spoken of here has no negative overtones. In Proverbs both the noun (cf 8:5,12) and the adjective (cf 12:16, 23; 13:16; 14:8; 22:3; $27: 12$ ) refer to the property of good judgement that enables one to make sharp decisions, that is, cleverness or astuteness as a feature of intelligence lacking in the foolish.

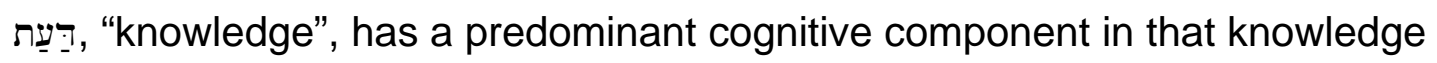
can be acquired by taking note of what one experiences (e g Pr 5:6; 23:35), but also by intentional effort (e g Qoh 2:21). However, it entails more than theoretical comprehension and can also denote intimate familiarity with a person (Gn 29:5; Jr 31:34 ${ }^{5}$ ) or acquaintance with an object and therefore the ability to care for it ( $\operatorname{Pr} 12: 10 ; 27: 23)$. This makes it the most comprehensive term for knowledge, which can be used as a synonym for חכמה (cf Pr 1:7;

\footnotetext{
${ }^{5}$ Perhaps a personified use of חכמה can also be seen in Qoh 7:12: "The advantage of knowing Wisdom is: she gives life to her husband."
} 
9:10; Qoh 1:16, 17; 2:26; 9:10), whereas, when used as a verb, it can have חכמה as its object (as in v 2 above).

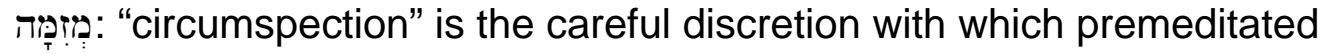
decisions are made $(\operatorname{Pr} 2: 11 ; 3: 21 ; 5: 2 ; 8: 12)$. Its semantic range is very

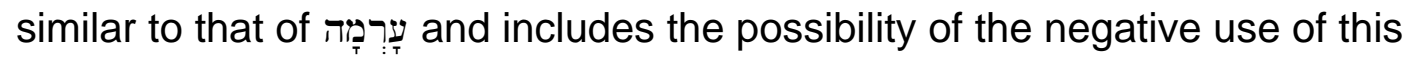
faculty (e g $\operatorname{Pr} 12: 2 ; 14: 17 ; 24: 8$ ). Neither term presupposes a moral quality, but both are among the intellectual powers considered to be "inherently conducive to morality" (Fox 2000:61) and are therefore not so neutral as Fox suggests when used as here.

נַעַ: The primary recipient of wisdom instruction is the young Israelite boy. He

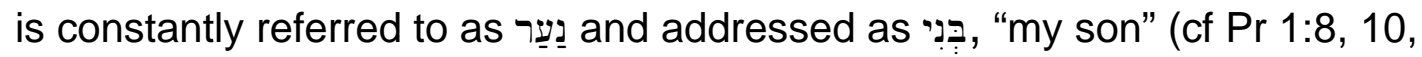
$15 ; 2: 1 ; 3: 1,11 ; 13: 22 ; 15: 11 ; 17: 6$ etc).

The new beginning with the introduction of a jussive ( $v 5$ ) and its expansion with another final infinitive construction ( $v$ 6) mark the next unit in the preface.

$5 \quad$ Not only the young may benefit from the contents of the book, but also the established sage (נחָָ ) who already has understanding (נבון). This verse is often regarded as a later addition, breaking as it does the series of infinitives starting at $\vee 2$. But whether this is so or not, it makes perfect sense in its present position and form. The jussive יש: ing not the indication of a clumsy interpolation, but necessary to indicate a new beginning. Now the readers are directly addressed. This is no longer the subtitle of the book, but a miniature foreword in which the first-tear users of the book are addressed: the wise who already have understanding. Of course the wise have learning and skills already, but if they take note of the contents of this book, they will add to these.

לְקָ: The learning which is received (לקח) by one generation and passed on to the next (explicitly described in Pr 4:1-4 and associated with דעת , מוסר and תורה, "teaching"), that is, the traditional body of knowledge enabling a sage to navigate through life. Fox (2000:62-63), in showing that this word is primarily associated with speaking (cf $\operatorname{Pr} 7: 21 ; 16: 21,23$; Dt 32:2; Job 29:23f) provides support not only for the understanding of לק לק the passing on of learning, but also (against his intention) for interpreting לִדָבִין in v 6 as causative (see below). 
תחתבּלוֹת : A It possibly related to חבל, "sailor" and may suggest the idea of navigating through life (Gemser 1963:18, Whybray 1994:34), similarly rendered in the Septuagint: $\left.\kappa \cup \beta^{\prime} \rho \nu \eta \sigma \iota \nu \kappa \tau \eta ́ \sigma \epsilon \tau \alpha \iota\right)$. If this is right, it vividly illustrates the view of wisdom as life-skills (Lebenskunde). In any case it indicates the use to which the received sapiential tradition can be put in instructing the young.

6 Of what this addition consists, is now added. The infinitive לִדין is the Hiphil infinitive construct of the verb בין. Similar to the Qal forms of this verb, the Hiphil may mean "understand" (as in v 2), but often occurs in the meaning "bring to understanding", "to impart understanding, "clarify". The personal object can be formulated with ? (e g Job 6:24) or the accusativus personae (e. g. Is 28:9; 40:14; Neh 8:8), but need not be expressed (e. g. Is 28:19), whereas the matter being clarified may be introduced by $?$ (e. g. Neh 8:7) or may stand in the accusativus rei (Is 28:9, 196; Job 6:24). The latter is the case here.

Fox's objection that "whenever the causative use of this verb ... governs a single object, this is always the semantic indirect object (the person who receives the teaching), not the semantic direct object (the substance or message taught)" excludes relevant evidence. The question is not what happens when the causative use of the verb has one object, but whether it can govern a direct object at all, and of this we have at least two clear examples (Is 28:9; Job 6:24) and another possible one (Is 28:11). Moreover, his own view that "Proverbs 1:5a is offering to enhance the wise man's rhetorical skills in teaching," matches a causative understanding of בין in v 6 better than a non-causative.

In our verse the personal object is not expressed and the matter to be clarified is a fourfold accusative construed in a rigid synonymous parallelism (proverb // words of the wise; figure // their riddles). It is nonsensical to require a sage to listen so that he may himself acquire the competence to understand a

\footnotetext{
${ }^{6}$ This is also the interpretation of the major German versions of Is 28:19; Luther ("Offenbarung deuten"), Elberfeld ("die Botschaft verständlich machen") and the Einheitsübersetzung ("das Gehörte erklären"). It is also possible that this is the sense of the Hiphil found in Pr 8:5a: "Teach the simple shrewdness." This would require the "men" and "people" addressed in 8:4 to be interpreted as humankind generally who should bring their inexperienced young to understand what shrewdness is, whereas the often proposed emendation of the second imperative ( $(v 5)$ from הכינו tould become plausible as a consequential clause declaring the intended consequence of the fulfilment of the first imperative: "Teach simple people understanding of shrewdness, so that the stupid may get their heart/mind in order" (cf below on Pr 8:5).
} 
proverb, since being a man of wisdom and understanding he already entails that capability. But if the sage listens to (that is, makes attentive use of) this book, his already existing learning may be expanded by the additional didactic skill of communicating the sense of proverbs, figures, riddles and other sapiential sayings. Therefore the verse neither is a mere statement of the obvious fact that both inexperienced young people (v 4) and established sages ( $v 5$ ) may benefit from wisdom, nor does it simply point out that wisdom is a lifelong process (Whybray 1994:33). Although all of this is true (cf Pr 8:4$5 ; 9: 9)$, verses 5-6 go beyond the commonplace to bring the purpose of the book into sharper focus: reading the Book of Proverbs will benefit established sages in that their wisdom will be augmented by didactic abilities in the use of even the most enigmatic sapiential literary genres.

מִלִיצָה This word is uncertain and occurs only twice in the Old Testament (the other instance being Habakkuk 2:6, where it is also used in association with


suggests that those commentators are right who follow Schultens (figuratio), in suggesting it means a figure, allusion or difficult saying of sorts. ${ }^{7}$ But this does not mean that the reference to tropes and figures denotes an injunction to find figurative meanings in the collected aphorisms. Since teachers are supposed to be able to help pupils understand such "figures", that is, to explain them, the reference cannot be appealed to in support of such a sweeping thesis.

$7 \quad$ This verse articulates the guiding principle of the whole book and as such represents the redactor's view of wisdom as such. The statement is repeated with slightly different formulation (wisdom instead of knowledge) in Pr 9:10. All real knowledge begins with the fear of God. יִרֵֵת יהוה is an objective genitive and indicates recognition of Yahweh with the awe due to him, in other words: faith and its concomitant, obedience. The aspect of obedience is here highlighted in the second hemistich, where the sapiential discipline of accepting authority is said to be lacking in fools. The principle authority (ראשית) is God himself. The enterprise of wisdom is, therefore, religious. From the redactional perspective it means that the contents of the whole book are qualified by this condition. Being prepared to accept the authority of parents and teachers necessarily involves accepting that of God -

\footnotetext{
${ }^{7}$ This interpretation is already found in Albertus Schultens's commentary, Proverbia Salomonis. Versionem integram ad Hebraeum fontem expressit, atque commentarium adjecit,

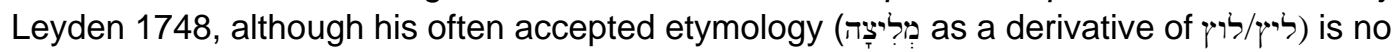
longer generally thought to be correct.
} 
first, because it is logically implied in the injunction of the authoritative teacher making this statement, and, second, because the whole sapiential system needs an ultimate authority, which can only be God as the Creator of the order implied in the norms invoked by the sayings and poems themselves. But the fear of God also has another side. It is also the limit of wisdom. The sages knew that their premises did not always work out. It could happen that wise conduct is not followed by favourable consequences and that wicked conduct is not punished. A poor man may not be poor because he is in the wrong and a rich man may not be rich because he deserves it $\operatorname{Pr} 28: 6$; cf the many adages where discrepancies in the theoretical mechanism of good $>$ good and bad > bad are noted, e g 10:22; 16:33; 19:21; 20:24; $21: 1$, 30f; 29:26). When things often do work out as the theory requires but often don't, it is obvious that there is an awe-inspiring power behind it all (cf 2 Sm 17:14). Therefore the fear of God is not only the beginning of wisdom, but also its end. Wisdom is limited and the only appropriate response is to accept it on the basis of awe. To be compared is the epilogue to the Book of Qohelet (Qoh 12:13), where the sum of Qohelet's wisdom is seen as an injunction to fear God. ${ }^{8}$ This insight has a variant in the piety of the Psalms, where fear of God and joy over his protection and blessing can be combined in harmony (Ps 22:24-26; 103:13; 128:1, 4; cf 25:12).

The conclusion to this exposition is, therefore, that "figures" or "tropes" may well be meant in verse 5 , but that the "cue" given is not about general figurative meanings encoded in the book. Rather, it is that teachers are to understand that the book is intended for them in order to enhance their adroitness in explaining figures and tropes and comparable difficult matters in need of clarification. Therefore the heavy emphasis on this verse as a pointer to read the whole book with a sensitivity to figurative aphorisms and motifs is greatly exaggerated.

\subsection{The endeavour to read aphorisms as if they "generally function figuratively"}

The strength of the idea that the prologue gives hermeneutical indications is that it highlights the fact that the aphorisms from chapter 10 onwards are in their present form determined by literary relationships no less than the poems

\footnotetext{
${ }^{8}$ Qohelet more than anyone underlines the severe limitations of wisdom (cf Qoh 6:8; 8:16-17; 9:16; 10:1; on the fear of God; cf 7:18) and it would be very surprising if the epilogist did not notice this. If he wanted to counter the restriction of wisdom by an "orthodox" remark, it is hard to understand why he would be willing to contribute to the handing down of an awkward book in the first place. It is equally unlikely that he thought he could neutralise the probing quality of a whole book, sharp as goads (cf Qoh 12:11), by one single remark. It may well be that the summary of the epilogist is not an illustration of almost unbelievable naiveté, but of understanding for the limitation of wisdom as exemplified by Qohelet.
} 
in chapters 1-9. This may of course indicate or invite several possibilities for understanding the anthology, including a metaphorical reading. The weakness is however that the idea cannot be generalised to such an extent that metaphorical readings are privileged. A further sweeping claim in support of this tendency should also be handled with care. Sandoval formulates it as follows: ${ }^{9}$

\begin{abstract}
... folk sayings are regularly intended and understood metaphorically. There exists a commonplace recognition that even though a proverbial utterance may make perfect sense when taken literally, it should not be so understood because proverbs by their "nature" (i e, their regular usage) are concerned to say something metaphorically about human beings, the world, or the ways and concerns of human beings in the world. More specifically, they are used to say something about the world and human beings in relation to quite particular contexts of human life.
\end{abstract}

He seeks support from the views of Archer Taylor and Wolfgang Mieder for the claim that "folk sayings are regularly intended and understood metaphorically" and from Peter Seitel that social context shows "how proverbs function metaphorically." ${ }^{10}$ Without entering into the matter of social context and its many ramifications, we should keep in mind that many aphorisms in the Book of Proverbs are not folk sayings and that all of them now are part of a literary context, both in the poems, where short sayings are often incorporated, and in the collections of short proverbs beginning at chapter 10. It seems fortuitous to on one hand make a basic point of the literary context or "Gestalt" of the Book of Proverbs in the light of the prologue as a hermeneutical cue for a metaphorical understanding, and on the other hand to make the same point regarding (or at least including) the social context whence the proverbs came before they were edited into a literary anthology in order to serve the same purpose. If such general statements on the character of the prologue and of aphoristic proverbs as they are generally intended and understood, are true, then the whole Book of Proverbs, not only a specific discourse within it, is to be understood metaphorically. Then the claim has to be that the book as such is primarily, if not exclusively, metaphorical. But, although the logic of his argument seems to require precisely that, Sandoval repeatedly states that he does not exclude nonmetaphorical understandings and only calls for more sensitivity for the

\footnotetext{
${ }^{9}$ Sandoval (2006:11); cf also p 118 and passim.

${ }^{10}$ Sandoval (2006:12); cf respectively Mieder (1993:9), Taylor ([1962] 1981:6), and Seitel ([1969] 1981:126-128).
} 
metaphorical meaning of some proverbs. ${ }^{11} \mathrm{He}$ seems to counter the force of his own argument by curbing its consequences. This is not only a question of formulation, since the whole book abounds with assurances of this "balanced" approach, whereas the evidence as interpreted presents an argument for only one side of it.

Having offered my response to his fundamental prologue-interpretation, I would now like to consider some representative proverbs in the light of the "generally" metaphoric quality aphorisms are said to have by virtue of their supposed kinship with folk sayings. There are many aphorisms where a metaphorical understanding is possible but unnecessary and others where such an interpretation is not possible.

In Proverbs 5:15 we have an aphorism in the context of a longer text:

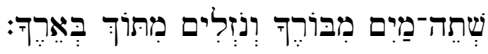

Drink water from your own cistern, running water from your own well.

This is a proverb from the injunction genre. It can stand by itself and be meaningful in its own right. As it stands in the context of verses 15-20, it is clearly part of an admonition on sexual satisfaction within marriage. The thrust is that sexual satisfaction is to be sought with one's own wife, not with other women ( $v 20)$, and that one's wife is not for sharing ( $v 17)$. There are notorious difficulties in the passage, such as the question whether verse 16 refers to a reward or has to be taken as an admonition or a threat, ${ }^{12}$ but the salient point for our purpose is the fact that we here clearly have a metaphor in the text and can only read it as a metaphor because the literary context makes another reading impossible. From verse 15 to verse 18 a string of water metaphors ${ }^{13}$ are used and then explicitly placed in a parallelism with "wife" (v 18):

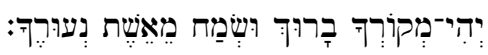

Blessed be your fountain, and rejoice in the wife of your youth.

\footnotetext{
${ }^{11}$ E g: Sandoval $(2006: 67,128)$; only an "overly literalistic" ( $p$ 130) or "overly literal" (p 141) reading is to be avoided, implying that he is defending a reading where a measure of the rejected literalism, but not too much of it, is acceptable.

${ }^{12}$ Fox (2000:200-202); cf Murphy (1998:32); Waltke (2004:317-319); Kruger (1987:60).

${ }^{13}$ Cf Klopper (2002:184-187).
} 
So we have no choice: the passage's concepts from the sphere of water (drink, water, cistern, well, springs, streams, fountain) are pinpointed by the context, which then moves on to another group of metaphors from the world of animals, again explicitly identifying the hind and the doe with the youthful wife as opposed to other women ( $\mathrm{vv} 19-20$, cf Ct 2:7, 3:5). But verse 15 is a typical proverb that, despite now being part of a literary unit, can just as well stand by itself in an aphoristic collection. It is therefore a saying that, in Sandoval's appropriation of Mieder cited above, is typical of those folk sayings that should be understood metaphorically because by their very nature they "say something metaphorically about human beings, the world, or the ways and concerns of human beings in the world." Let us consider this with the help of the example before us.

The line can very well be understood literally and still say things about the concerns of people in the world. For instance, in a dry land it is unwise to become dependent on others for water supplies. Therefore the wise man should see to it that he has his own water resources. The saying would be an injunction to economic independence and would focus on the interests of the individual spoken to. Second, if the addressee does have his own resources, he should not avail himself of those owned by other people. That would be an admonition in the spirit of Nathan's parable, an idea taken for granted by David, since he was angered by the narrative of a man who had enough of the same resource and still took from another's (2 Sm 12:1-6), and it would focus on the interests of society.

In Proverbs 9:17 water imagery is clearly again used in the service of a sexual ethic.

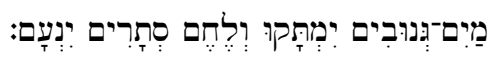

Stolen water is sweet, and bread eaten in secret is pleasant.

From the context we know that the pithy saying is spoken by Dame Folly in order to lure unwise men to her. This in itself is metaphorical, since the imagery of public soliciting by a woman in the city is clear. It stands for folly luring simple men. As such it could be understood metaphorically for illicit sex $^{14}$, but it could also be understood quite literally. The proverb by itself could be interpreted as an expression of the same logic used in Proverbs 20:17:

\footnotetext{
${ }^{14}$ Cf Waltke (2004:40, 445-446; 2005:145-146).
} 


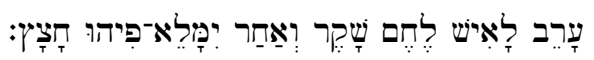

Bread gained by deceit is sweet, but afterward the mouth is full of gravel.

The second aphorism uses the so-called "synthetic" device to represent the consequences of theft by means of a clear metaphor for experiencing the unpleasant consequences of deceitful gain. The gravel in the mouth is a pointer that the eating of bread in the first hemistich is also a metaphor. But even so, the eating of bread can be a literal reference to food gained by deceitful means, for which the consequence can be most aptly indicated by a metaphor from the field of the literal eating. The first proverb, however, does not develop the consequences of the pleasure of illicit gain. In the context the suggestiveness of Dame Folly is clear, and in the context of a collection of poems including Proverbs 2:16-19 on illicit sexual behaviour and the water imagery of Proverbs 5, clearer still. But if we consider the proverb by itself, ${ }^{15}$ it can very well be understood literally. Drinking and eating what one has unlawfully gained, obviously has a fascination, since it lures people so generally that it can be said that it always provides the additional thrill of adventure. ${ }^{16}$ The repetitive expression of the principle in the parallelism leaves no room for pointing out the consequence as in Proverbs 20:17. Therefore there is a hole in the text, which has to be filled up by the hearer. ${ }^{17}$ But nothing absurd results, and the proverb can be as suggestive as any when taken literally.

As a last example of this kind, we may consider Proverbs 24:17-18:

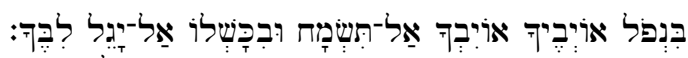

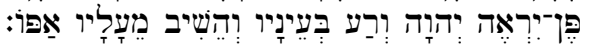

Do not rejoice when your enemy falls, and do not let your heart be glad when he stumbles,

So that Yahweh not see it and it be wrong in his eyes, and turn away his anger from him.

\footnotetext{
${ }^{15}$ Suggested but not pursued by Murphy (1998:61).

${ }^{16}$ Similarly Fox (2000:302).

${ }^{17}$ The same logic is found in the Arabic proverb, "Anything forbidden is sweet" (cf Winton Thomas 1965:271-279). The invitation to think further in line with the suggestive text also occurs at the endings of the Book of Jonah and the Gospel of Mark, where the anti-climax likewise calls for participation by the reader; cf also the many holes in the Book of Esther, also invitations to contribute to the meaning.
} 
Here the aspect of interest for us is whether we have a metaphor in the way that God's observation of human conduct is described. A human being rejoices over the ill fortune of an opponent, God sees it and as a result takes the side of the underdog. The anthropomorphic speech may indeed be a metaphor, that is, the proverb speaks of God as if he were human. This obviously has to do with the idea that God has physical features as humans do, in this case eyes to look out of. But the proverb could also be understood literally. That would depend on the concept of God lying behind the proverb. Is the God spoken of here pictured naively, which happened all over the Ancient Near East, as a personal being who walks around, observes things and makes decisions on that basis? If so, then the anthropomorphism is not meant metaphorically, but literally in terms of the anthropomorphic concept of God. If the God concept lying behind the proverb is however not that God somehow

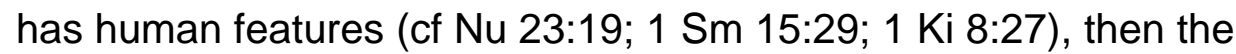
anthropomorphism does represent a metaphorical way of speaking about him. Then it intends to say something that has to be said but can only be said metaphorically for lack of ways in which to conceptualise the inconceivable. So the question of metaphorical features in the text can also depend on issues of ancient Israelite religious history.

In all of these cases there is no sign of an absurdity occurring as a result of a literal understanding of aphorisms when they are read in their own right. The absurd result Sandoval, following Ricœur (1976:50), ascribes to efforts at understanding such proverbs literally, is to be expected if both the literary shape introduced by the prologue keynote and the nature of aphorisms point in that direction. But it does not happen. If absurdity or self-destructing contradiction is a sign that a metaphor is present (Sandoval 2006:7), we do not have metaphors here. If such aphorisms are a "difficulty" since they lack absurd literal potential (Sandoval 2006:10), it begs the question why at all bother to get it to be a metaphor? Why at all stick to such a yardstick?

\subsection{Aphorisms that cannot be understood as metaphors}

My argument thus far suggests that there are levels of the text clearly indicating where metaphors are present in aphorisms, and other levels that allow literal readings. This may happen within the aphorisms themselves and sometimes on the level of the aphorisms in their context. But there are often cases where texts can not be read metaphorically unless the readers in their own right apply the proverb to a new situation and thereby create a metaphor. 

trade $^{18}$.

As a first series of examples I choose the aphorisms on scales and fair

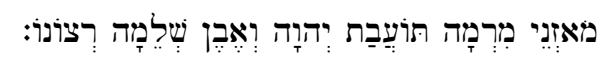

False balances are an abomination to Yahweh, but he favours an accurate stone.

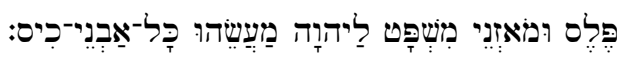

A just balance and scale are Yahweh's; all the stones in the bag are his work.

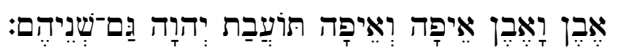

A stone and a stone, an ephah and an ephah - both of them an abomination to Yahweh!

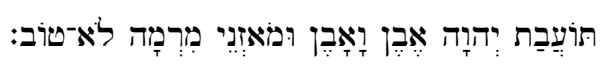

An abomination to Yahweh are a stone and a stone, and false scales are not good.

(Pr 20:23)

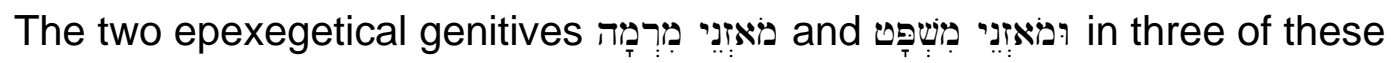
proverbs exemplify the opposites in the measurement scales used by merchants. They can also be understood as objective genitives: scales that bring about fraud and scales that cause justice to be done. The stones are the weights used on the scales. The repetition "stone and stone", "ephah and ephah" (Pr 20:10 and 23) imply two opposite kinds of measuring tools: too light for selling and too heavy for buying. ${ }^{19}$ The heavily moral word used to condemn such business practices in the strongest possible terms. ${ }^{20}$ The whole issue is distinctly religious and as such concerns a moral value, but

\footnotetext{
${ }^{18}$ Sandoval obviously has to treat them, since they are so important for his focus on economic motifs, although they sit uncomfortably with his thesis (cf Sandoval 2006:143-145).

${ }^{19}$ Cf Murphy (1998:151). The same kind of repetitive idiom is found in our parlance: There are friends and "friends", meaning, "Some friends are good and others are bad."

${ }^{20}$ Cf Dt 25:13-16; for the principle, cf further Lv 19:35-36; Ez 45:10-12; Am 8:5; Mi 6:10-12.
} 
this has nothing to do with non-literal understanding. The meaning is plainly and straightforwardly literal. The scales and the weights and the measuring units do not represent "higher" as opposed to "lesser" values (so often distinguished by Sandoval ${ }^{21}$ ). The literal meaning is a moral meaning. Of course the reader can apply these proverbs to other spheres of life, such as non-discrimination in politics, treating children equally, fair criteria for evaluation of examination papers, equal treatment for all language groups, consistent umpiring in LBW judgements and so on. But that does not declare the proverb to be a metaphor in its intentional historical or literary context, it shows the extent to which the reception of literal meanings is influenced by the reader and highlights the creativity of the interpreting subject.

A second group of examples is taken from the aphorisms on laziness. In two cases we have clear-cut metaphors, but the majority are quite literal.

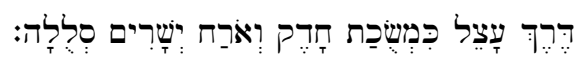

The way of the sluggard is like a thorn hedge, but the path of the upright is a highway.

(Pr 15:19)

In this antithetical saying there is a metaphor and a simile. The way (both דִ? and ארֵז) is the life course, including the conduct and the experience of humans. In terms of the metaphor the last hemistich is quite literal: a highway ארֵז (סלל איה), but for that reason it extends the metaphor: The metaphor says that, whereas a sluggard's life is "thorny", that is, cumbersome, the upright make easy progress. The proverb contains a metaphor, but the metaphor has nothing to do with laziness. That is to say that the aphorism has something to say about literal laziness, but does so by using the metaphor of the way. Moreover, an endeavour to understand the metaphor literally does not produce the kind of Ricoeurian absurdity: it is quite thinkable that a lazy traveller takes a shortcut to avoid too long a walk along the road, and finds himself hindered by thorny bushes, while a wise man keeping to a longer but tested "beaten track" finds walking to the destiny easier. So, although we do have a metaphorical aspect in the, aphorism, the criterion that its literal interpretation should "produce an immediate or unambiguous absurdity" is not met. Sandoval (2006:13) finds this a "problem", but it is only a problem in terms of his interpretation of Ricoeur that it should be.

\footnotetext{
${ }^{21}$ Cf Sandoval (2006:92, 130 and passim) in several contexts. An appeal to the prologue (Pr $1: 3$ ) does not remove the principle of social justice from the literal sphere (Sandoval 2006:145).
} 


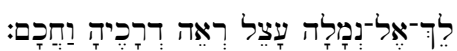

Go to the ant, you sluggard, consider its ways, and be wise.

$(\operatorname{Pr} 6: 6)$

Part of the section 6:6-11 on laziness, this command is a complete sapiential injunction in its own right. The ant is an example of diligence (cf $\operatorname{Pr} 30: 25$ ), but the saying does not become a metaphor for that reason. The sluggard is to literally study the ant and do as the ant does in order to provide food for the time of need. ${ }^{22}$

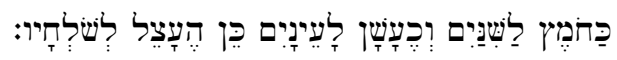

Like vinegar to the teeth and smoke to the eyes, so the sluggard to his senders.

In this saying (Wahrspruch) we do have a figure, but not a metaphor. It is a direct comparison between the effects of sending a sluggard on an errand and the negative and painful experience of vinegar on the teeth and smoke in the eyes. The point is quite literally to state that employment of a lazy person brings about negative consequences. It is left to the hearer to infer that such employment should be avoided. ${ }^{23}$

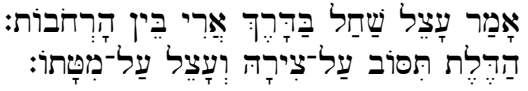

The lazy person says, "There is a lion on the road! There is a lion in the streets!"

A door turns on its hinges and a sluggard on his bed.

(Pr 26:13-14)

These two aphorisms obviously occur together because of the shared motif of laziness. Beginning with the second one, this is also clearly a complete metaphor in which the things compared are stated (cf Waltke 2004:39), but without $כ$ and/or $כ$. The metaphor exemplifies the fact that a sluggard gets

\footnotetext{
${ }^{22}$ Cf Toperoff (1985:179-185).

${ }^{23}$ Cf Loader (2001:201-209).
} 
nowhere. His movement is like the movement of a door on its hinges, it stays only where it stands. This brings an important element of humour into the aphorism, which, again, serves to ridicule sloth. The literal element is however again quite apparent. The sluggard only turns around in bed, unwilling to get up and work. The turning sluggard on his bed "is" a turning door on its hinges. The only reason why it is called a metaphor and not a simile is that the particle of comparison $\boldsymbol{D}$ is absent. But a "complete" metaphor expressly measures the literal thing compared with the metaphorical figure.

The former of the two aphorisms ( $\operatorname{Pr} 26: 13)$ has a parallel in chapter 22:

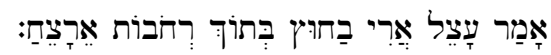

The sluggard says, "There is a lion outside! I shall be killed in the streets!"

$(\operatorname{Pr} 22: 13)$

These are literal aphorisms, not metaphors. Whether there actually is a lion outside is irrelevant, because the extravagance of the reason for not going out and being active serves to ridicule the sluggard by unmasking the (real) absurdity of his excuses for doing nothing. It is humour again employed to evoke a negative response in the hearer. Therefore the literal understanding of the sluggard's words is necessary for the point of the aphorism to be grasped: lazy people stop at nothing to do nothing. It is then suggestively left to the reader to supply the consequence that laziness is to be avoided.

We can continue in this vein with many aphorisms on trustworthiness (e $g \operatorname{Pr} 11: 3 ; 13: 17 ; 26: 6$ ), human speech (e $g \operatorname{Pr} 15: 1,2,4$, 28; 25:15), the royal court (e g $\operatorname{Pr} 16: 14 ; 19: 12 ; 20: 2$ ), women (e g Pr 2:16; 5:2; 7:5) and so on. The question whether such aphorisms contain metaphors or not, is to be distinguished from the question whether they are to be understood metaphorically or not. Even on the submission that these aphorisms are "about virtue and vice", the conclusion is not warranted that this makes them more metaphorical (Sandoval 2006:138) or that their "moral values" should be contrasted with "literal" things understood as "material" things or "lesser goods" (Sandoval 2006:118 and passim).

\section{CONCLUSION}

My purpose in this article was to show that a sweeping general claim for more willingness to interpret aphorisms of one discourse or group of discourses "more" metaphorically, can be substantiated neither on the basis of the overall 
literary context (the "hermeneutical cue" of the prologue) nor on the basis of vague paremiological suppositions about aphorisms (that short proverbs have much in common with folk proverbs, most of which "naturally" require metaphorical understanding). Generalised statements on the basis of the literary Gestalt of the anthology (whether this is called the redactional perspective or not) have to be generally applicable or not at all. And equally generalised perceptions on the "nature" of aphorisms have to be equally applicable overall if they are to have argumentative value. Moreover, this kind of argument runs the danger of applying a petitio principii: aphorisms naturally tend to say more than they seem to say, so they do that here as well. There certainly is a coherence to be seen in the Book of Proverbs, not only because a hermeneutical framework is provided by the prologue, but it can also be observed in the use of sapiential perspectives (such as the creational order, the deed-consequence nexus and the religious mooring of wisdom) and motifs (such as the concept of wisdom, discipline and human possibilities). It can also be seen in the impressive literary employment of figures, including metaphors, and of other possibilities offered by poetry, as these occur throughout the book. But the topics covered are so variegated that we should not give in to the temptation to employ a specific strategy in order to satisfy a need to discover coherence in the book. Rather, exegesis should opt for interpretive acts with creative theological possibilities. As Wencislaus Link did in his criticism of the papal withholding of the biblical abundance from the people. He says: ${ }^{24}$

The wise Solomon says in Proverbs 11: "The people curse him who withholds grain, but there is a blessing on the head of him who sells it."

In this literal aphorism, people curse merchants for manipulating prices by withholding grain from the market. The monopolistic merchant becomes a metaphor for the pope, his withholding grain metaphorically stands for the papal withholding the bread of life in the Bible from the hungry, the common people of Europe are kept in the power of the church as the Israelite populace are kept in the power of the merchant. Luther, on the other hand, would be the one who puts the food at the people's disposal by translating the Bible into the tongue of the people, and is blessed for it. On a second level, Link himself puts Luther's essay on Bible translation at public disposal, claiming that he just cannot withhold it, and can also hope for the sapiential blessing on his

${ }^{24}$ Luther ([1530] 1909:632). The reference is to $\operatorname{Pr} 11: 26$. 
own head. Whether one agrees with this application or not, is not decided by the question whether the proverb can be shown to need a "more metaphorical" interpretation than usual. It is decided by one's views on the Reformation and issues of the authority of the church. This is not a "right" interpretation reckoning with literary and paremiological reasons for reading metaphorically. But it is a legitimate metaphorical application of a literal proverb.

\section{Works consulted}

Bernhardt, K-H (Hg) 1971. Schalom: Studien zu Glaube und Geschichte Israels. Alfred Jepsen zum 70: Geburtstag dargebracht von Freunden, Schülern und Kollegen. Stuttgart: Calwer Verlag. (AzTh Reihe 1, 46.)

Fox, M V 2000. Proverbs 1-9: A New translation with introduction and commentary. New York: Doubleday.

Fuhs, H F 2001. Das Buch der Sprichwörter: Ein Kommentar. Würzburg: Herder. Gemser, B 1963. Sprüche Salomos. Tübingen: J C B Mohr. (HAT 16.)

Ho, A 1991. Sedeq and Sedaqah in the Hebrew Bible. New York: Peter Lang.

Klopper, F 2002. Oë in die wildernis: Die religieuse funksie van fonteine en putte in die Hebreeuse Bybel: 'n Godsdienshistoriese studie. Pretoria: Diss Unisa.

Kruger, P A 1987. Promiscuity or marriage fidelity? JNSL 13, 61-68.

Loader, J A 2001a. Lernen im Indikativ, in Loader 2001b:201-209.

Loader, J A 2001b. Begegnung mit Gott: Gesammelte Studien im Bereich des Alten Testamentes. Wien: Peter Lang. (WAS 3.)

Loader, J A 2004. Virtue between command and advice. Old Testament Essays 17, 416-434.

Luther, M [1530] 1909. Ein sendbrief D M Luthers: Von Dolmetzschen und Fürbit der heiligenn. WA 30(2), 632-646.

Mieder, W 1993. Proverbs are never out of season. Oxford: OUP.

Mieder, W \& Dundes, A (eds) 1981. The wisdom of many: Essays on the proverb. New York: Garland.

Murphy, R E 1998. Proverbs. Nashville: Nelson. (Word Biblical Commentary 22.)

Plöger, O 1984. Sprüche Salomos (Proverbia). Neukirchen-Vluyn: Neukirchener erlag. (BK 17.)

Ricoeur, P 1976. Interpretation theory: Discourse and the surplus of meaning. Houston: TCUP.

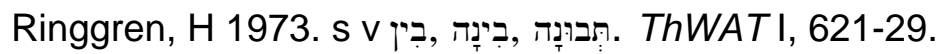

Seitel, P [1969] 1981. Proverbs: A social use of metaphor, in Mieder \& Dundes (eds), 1981:122-139. (Original: Genre 2 [1969], 143-161.)

Sandoval, T J 2006. The discourse of wealth and poverty in the Book of Proverbs. Leiden \& Boston: E J Brill. (Biblical Interpretation Series Volume 77.)

Taylor, A [1962] 1981. The wisdom of many and the wit of one, in Mieder \& Dundes 1981:3-9. (Original: Swarthmore College Bulletin, 59 [1962], 4-7.)

Toperoff, S P 1985. The ant in the Bile and Midrash. Dor le Dor 13:179-185.

Waltke, B 2004. The Book of Proverbs: Chapters 1-15. Grand Rapids, MI: Eerdmans. (NICOT.) 
Waltke, B 2004. The Book of Proverbs: Chapters 15-31. Grand Rapids, MI:

Eerdmans. (NICOT.)

Westermann, C 1971. Weisheit im Sprichwort, in Bernhardt 1971:73-85.

Whybray, R N 1994. Proverbs. Grand Rapids, MI: Eerdmans (New Century Bible Commentary.)

Whybray, R N 1982. Qoheleth, preacher of joy. JSOT 23, 87-98.

Winton Thomas, D 1965. Notes on some passages in the Book of Proverbs. VT 15, 271-279.

Zimmerli, W 1933. Zur Struktur der alttestamentlichen Weisheit. ZAW 51, 177-204. 